\title{
ESTABLISHING AMERICAN LITERATURE THROUGH JAMES FENIMORE COOPER'S THE DEERSLAYER
}

\author{
Mia Fitria Agustina \\ Jenderal Soedirman University
}

\begin{abstract}
It is known that American Literature, at the beginning, was influenced by the writers' mother lands as they immigrated to America. That is why, the first generation writers in America started to think about how to produce the real American's works. To do this, those first generation writers started to find out what are American distinctive features, and put those characteristics in their works in order to establish American Literature. James Fennimore Cooper is one of the writers. His works are admitted as works which expose those American distinctive features. Among Cooper's works are Leatherstocking Tales. These tales consists of The Deerslayer, The Last of the Mohicans, The Pathfinder, The Pioneers, and The Prairie. The Deerslayer is the first part of the tales based on the character's age. In The Deerslayer, the features of American are exposed both directly and indirectly, and it is a challenge to figure out those features. Therefore, this paper is trying to seek those distinctive characteristics in The Deerslayer by James Fennimore Cooper's and their significance.
\end{abstract}

Keywords: distinctive characteristics, American Literature, James Fennimore Cooper, Leatherstocking Tales, and The Deerslayer.

\section{INTRODUCTION}

It is easier to write something that we know well than if we have to write something that we do not know well. However, James Fennimore Cooper wrote 
books which mainly talk about Indians in at least five of his (The Deerslayer, The Last of the Mohicans, The Pathfinder, The Pioneers, and The Prairie). As he is white, the fact about writing Indians (the red people) becomes something interesting to be analyzed deeper.

Moreover, previously, the written works in America were strongly influenced by writers' mother land. This kind of fact is not a surprise as it is known that the original people of America are Indians. The white came to America to find a better place to live. As they did not come from America, it cannot be denied that their origin colored their writings. However, this was gradually changed as the first generation born. These writers started to think about the unique characteristics of their writing and put those in their masterpieces. One of them is James Fennimore Cooper. Cooper tried hard to put those characteristics in his writing. Therefore, it is interesting to figure out these unique characteristics in Cooper's writing.

Furthermore, among Cooper's works, Leatherstocking Tales are famous ones, and The Deerslayer is the first based on the character's age. In this novel, Natty Bumppo, the main character, is about twenty years old. He was born as a white person, yet he lives among the Indians. When a novel mentions Indians, moreover; it tells the story of Indians, it cannot be denied that this novel exposes an American feature as Indians are inseparable part of American. There must be more than this fact mentioned about American features in the novel. That is why this paper purpose is to find out what distinctive characteristics mentioned in The Deerslayer by James Fennimore Cooper and their significance in establishing American Literature as one of the nation's identity.

\section{DISCUSSION}

There are several distinctive characteristics which show American's characteristics in The Deerslayer. Among those are the involving of Indians, the setting, and the searching of the main character's identity. To begin with, as it is mentioned in the introduction, the novel is about a white person who lives among Indians. How this white person lives in Indians communities has already proved that this writing includes American characteristics. Indians live in America. Nowhere in this world can be associated with Indian than America. When we mention Indians, directly, we think about America. That is why this already proves that this writing starts to put American features in the work. Moreover, putting 
Indians in the works also shows and tells to the world that America is a country, and Indians are part of this country. Presenting Indians which are different from the rest of countries in the world proves to the world that America, especially American literature is different. Therefore, involving Indians in the novel, as one of the distinctive features, shows that America especially American literature is unique.

The second distinctive feature used in the work is the wilderness. There is no place which can show wilderness as America. Wilderness is known as a place where community and consensus would be put in peril by the total absence of European law, religion, and civilization; besides, it is as an unknown entity with bizarre animals, unusual topography, and strange indigenous inhabitants (Nash qtd. in Johns, 2010). These representations can be seen in almost every part of The Deerslayer. Moreover, the readers are introduced to wilderness since the first chapter in The Deerslayer. This is one of the examples,

Broad belts of the virgin wilderness not only rhed the shores of the first river, but they even crossed it, stretching away into New England, and affording forest covers to the noiseless moccasin of the native warrior, as he trod the secret and bloody war-path. A bird's-eye view of the whole region east of the Mississippi must then have offered one vast expanse of woods, relieved by a comparatively narrow fringe of cultivation along the sea, dotted by the glittering surfaces of lakes, and intersected by the waving lines of river. In such a vast picture of solemn solitude, the district of country we design to paint sinks into insignificance, though we feel encouraged to proceed by the conviction that, with slight and immaterial distinctions, he who succeeds in giving an accurate idea of any portion of this wild region must necessarily convey a tolerably correct notion of the whole (page 2-3).

That example totally shows how The Deerslayer describes wilderness. That presents that the nature is unspoiled. It shows also how beautiful the nature is. Moreover, it also presents that nature's beauty is a path to spiritual and moral development. Furthermore, wilderness impresses the mind with awe in the shade and silence of the vast forest. In the deep solitude, alone with nature, we converse with GOD (Harris qtd. in Nash, 58). Thorough the choosing word that is "solemn solitude," it is a fact that this nature's beauty becomes the path to be closer to God.

Besides, two characters in the novel, The Deerslayer and Chingachgook, also shows the reader about contemplating nature's beauty as a path to spiritual and moral development. On page 21-22, there is an expression on how The Deerslayer feels the power of God. This expression is started by his admiration of the nature 
that he sees during his journey with Harry Skurry, another character in the novel. In this part, The Deerslayer becomes the witness of natural beauty as The Deerslayer feels the presence of God through the description of unspoiled nature. He says,

"This is grand! -- 'tis solemn!- 'tis an edication of itself, to look upon!" exclaimed Deerslayer, as he stood leaning on his rifle, and gazing to the right and left, north and south, above and beneath, in whichever direction his eye could wander; "not a tree disturbed even by red-skin hand, as I can discover, but everything left in the ordering of the Lord, to live and die according to his own designs and laws! ... (page 21-22)."

Almost the same as The Deerslayer, Chingachgook also studies the shores of the lake, the mountains and the heavens, with the sagacity of a man of the woods, and the gravity of an Indian (page 442). This proves once more that nature has its own way to present God within its beauty.

This beautiful setting which depicts wilderness shows clearly that this novel uses the American identity. That is why, even though Cooper, Susan (Cooper's wife) and the children moved to Europe as Cooper served as United States Consul in Lyons, France, and also traveled to many other countries including Italy, Switzerland, England, and The Netherlands, Cooper was still capable to write about America as in 1833, the Coopers returned to the United States, settling in Cooperstown. Besides that, Cooper also made many trips to New York, Philadelphia, and Baltimore. He, then, stayed in New York. He knew New York well and he expressed what he knew in The Deerslayer. The setting which shows the wilderness in the novel is New York itself that time. It is especially the setting of Otsego Lake. It is Cooper's knowledge of Otsego Lake which causes him wrote each of rock and cove. This statement is supported in the Illustrations part of The Deerslayer. In this part it is mentioned, "Copper knew Otsego Lake from his boyhood, and brought every rock and cove into The Deerslayer."

Finally, it can be said that the setting is one of the distinctive characters which shapes American Literature. As it is explained before, the wilderness is the distinct feature which is only possessed by America. By presenting this wilderness in The Deerslayer as the setting, Copper has a purpose to show to the readers that this novel depicts America. The readers can feel, see, and hear about wilderness. The readers also can be part of witnesses who could not agree more that the features of wilderness is the one and only possession possessed by American through the narrations and dialogues among the characters in the novel. 
The next thing which shows the distinctive character of America in The Deerslayer is shown by the main character's effort to search his identity. As it is mentioned before, the main character, Natty Bumppo, lives between two worlds, the red and white world. He experiences what is called identity negation as identity negotiation. It may arise from the learning of social roles through personal experience. It also means that he experiences a process in which a person negotiates with society at large regarding the meaning of his or her identity because he lives in two different worlds. This negation, later on, shapes the distinctive character of America. This can shape American identity since The Deerslayer mainly talks about the red men and the white men. The red men are also known as the native America. Therefore, talking about the red men can be considered as talking about America. Moreover, the word wilderness is also represented by the red men. The red men live in wilderness. They take care wilderness. They only take what they can take from wilderness. As the white man who came to America, this white man wants to have their own identity which may be different from the previous identity, the Europe one. Therefore, blending the white and the red can be the alternative to shape the identity.

The journey to find The Deerslayer identity starts when the writer compares both his physical appearance and character with Henry March. Henry March was described as a ... noble specimen of vigorous manhood .... His nick name was Hurry Skurry, a nickname he had obtained from a dashing, reckless offhand manner, and a physical restlessness that kept him so constantly on the move, and caused him to be known along the whole line of scattered habitations that lay between the province and the Canada. The stature of Hurry Harry exceeded six feet four, and being unusually well proportioned, his strength fully realized the idea created by his gigantic frame. The face did no discredit to the rest of the man, for it was both good-humored and handsome. His air was free, and though his manner necessarily partook of the rudeness of a border life, the grandeur that pervaded noble a physique prevented it from becoming altogether vulgar (page 4$5)$.

Different from Henry March, The Deerslayer was about six feet in his moccasins, but his frame was comparatively light and slender, showing muscles, however, that promised unusual agility, if not unusual strength. His face would have had little to recommend it except youth, were it not for an expression that seldom failed to win upon those who had leisure to examine it, and to yield to the 
feeling of confidence it created. This expression was simply that of guileless truth, sustained by an earnestness of purpose, and a sincerity of feeling, that rendered it remarkable. At times this air of integrity seemed to be so simple as to awaken the suspicion of a want of the usual means to discriminate between artifice and truth; but few came in serious contact with the man, without losing this distrust in respect for his opinions and motives (page 5).

There are also some other different between Henry March (Harry) and The Deerslayer, for example, the age, their attire, and the rifle. Besides, their moral views are also different. It is explained when Harry offers The Deerslayer cold venison steak of a doe that would have made an entire meal for a European peasant; ... which according to The Deerslayer is not right as there's little manhood in killing a doe, and that too out of season; ...(page 6). This statement of The Deerslayer describes how the Indians value is applied. He refuses to kill the doe for fun. If he kills the deer, it is because he needs it to survive. This fact proves to the readers that Cooper as the writer loves animals and this goes along Indians values.

The next difference is also shown when they talk about Delaware. Harry thinks that they are no heroes while The Deerslayer thinks oppositely. There are other different views between them about killing people too. Harry says that it is fine to kill people when they cause harm to him as he says, "Why not! If an enemy crosses my path, will I not beat him out of it ! Look at me ! am I a man like to let any sneaking, crawling, skin-trader get the better of me in a matter that touches me as near as the kindness of Judith Hutter! Besides, when we live beyond law, we must be our own judges and executioners. And if a man should be found dead in the woods, which is there to say who slew him, even admitting that the colony took the matter in hand and made a stir about it? (page 6)"

When they talks about Indian, it is also clearly that they have a very different opinion. As Harry think that being white is the best, he is underestimate black and red by saying that they are not equal with him.

Here's three colors on 'arth: white, black, and red. White is the highest color, and therefore the best man; black comes next, and is put to live in the neighborhood of the white man, as tolerable, and fit to be made use of; and red comes last, which shows that those that made 'em never expected an Indian to be accounted as more than half human."

"God made all three alike, Hurry."

"Alike! Do you call a nigger like a white man, or me like an Indian?" 
"You go off at half-cock, and don't hear me out. God made us all, white, black, and red; and, no doubt, had his own wise intentions in coloring us differently. Still, he made us, in the main, much the same in feelin's; though I'll not deny that he gave each race its gifts. A white man $\mathrm{s}$ gifts are Christianized, while a redskin's are more for the wilderness. Thus, it would be a great offence for a white man to scalp the dead; whereas it 's a signal vartue in an Indian. Then ag'in, a white man cannot amboosh women and children in war, while a redskin may. 'T is cruel work, I '11 allow; but for them it 's lawful work; while for us, it would be grievous work (page 36)."

This conversation proves how different Harry and The Deerslayer. The Deerslayer thinks that here is no different among three races as God creates them equally. He also gives example that the different among them especially the white and the red do not make them different as Good creation because it's only emphasizes how they have their own way to live by obeying rules among their color. Therefore, according to The Deerslayer, there is no need to be argued that although there are some differences, yet there are some likenesses. What can be done is to respect these differences to create the harmony.

How The Deerslayer and Harry are not alike is also shown when they face God's creation. When these two men discover the ark, as the floating habitation of the Hutters, which is a very simple contrivance, they give different responds. Hurry leaped on board, and in a minute was closely engaged in a gay and a sort of recriminating discourse with Judith (a character in the novel), apparently forgetful of the existence of all the rest of the world. Not so with Deerslayer. He entered the ark with a slow, cautious step, examining every arrangement of the cover with curious and scrutinizing eyes. It is true, he cast one admiring glance at Judith, which was extorted by her brilliant and singular beauty; but even this could detain him but a single instant from the indulgence of his interest in Hutter's contrivances. Step by step did he look into the construction of the singular abode, investigate its fastenings and strength, ascertain its means of defence, and make every inquiry that would be likely to and make every inquiry that would be likely to occur to one whose thoughts dwelt principally on such expedients. Nor was the cover neglected. Of this he examined the whole minutely, his commendation escaping him more than once in audible comments (page 53).

Another difference between Harry and The Deerslayer is shown through Judith character. She thinks that The Deerslayer is far better than Harry in many ways. One of these is when they have different opinion about scalping Indians. 
Harry thinks that his religion is allowed that happens as it is ok to do what people do, "One good turn deserves another." In different side, The Deerslayer says that as white they may not do scalping as it is Indian's. Therefore, Judits says "Father, father! think no more of this, and listen to the advice of Deerslayer, who int, has a conscience; which is more than I can say or think of Harry March (page 77)."

These differences show to the readers that Copper wants to present the two worlds through those characters. Harry's character represents people who does not leave in New World (Europe ones) yet, while The Deerslayer represents American's people as he is mixed between white and red. The Deerslayer has the qualities of real American's people. The love of the external nature and the attitude towards animals, also the way to see the world as equal world between three races; Indian, white, and black; are some of those qualities.

Name is also other way to show to the reader how the main character searches his identity. When the reader read the novel without seeing the illustration of the novel, the reader will think that The Deerslayer is an Indian. However, the meeting between The Deerslayer and Judith reveals the real background of The Deerslayer. In that meeting Judith asks The Deerslayer his name. When people are asked about their name they will answer the question directly, yet it does not happen to The Deerslayer. Instead he answers the questions, he reply Judit's question by saying, "That's a question more easily asked than it is answered, young woman, seeing that I'm so young, and yet have borne more names than some of the greatest chiefs in all America (page 55)." This answer indicates that because he is young, it is understandable that his name is not as great as chiefs in America. Chief here refers to Geronimo or Indian leader. When people becomes chiefs, they will have great name as name in Delawares settle on a man's ra'al title, until such time as he has an opportunity of showing his true natur', in the council, or on the warpath; which has never be happened me [The Deerslayer]; seeing firstly, because I'm not born a red skin and have no right to sit in their councillings, and am much too humble to be called on for opinions from the great of my own color; and, secondly, because this is the first war that has befallen in my time, and no inimy has yet inroaded far enough into the colony, to be reached by an arm even longer than mine (page 55)." Therefore, it can be concluded that the answer shows how he thinks that he is an Indian, although he is white.

Moreover, The Deerslayer reveals his white name after Judith asks him several times. That is why before he mentions his name, he explains to Judith that, "I 'm Christian, and white-born, like yourself, and my parents had a name that came 
down from father to son, as is a part of their gifts. My father was called Bumppo; and I was named after him, of course, the given name being Nathaniel, or Natty, as most people saw fit to tarm it." Again, before telling Judith his given name, he mentioned his family name first. This, one more time, shows that he is very reluctant to mention his white name.

Later on, he explains more about how he gets his Indian name. Started with the name "Straight tongue" that he gets because the Delawares soon found out, or thought they found out, that I [The Deersayer] was not given to lying, ... (page 56). The Deerslayer is very proud with the name as he says that he deserved to be so called, lies being no favorites with me, as they are with some (page 56). Explaining his first Indian name to Judith, in this case, shows how The Deerslayer is happier to be Indian than to be white. Besides, he is happy with the name as he thinks it is suitable, for him for he never tells lies. Moreover, he tells Judith more about why his name is changed into "The Pigeon." Here, "The Pigeon" means a swift wing, and flies in a straight line, and he gets the name when The Delawares finds out that he is quick of foot.

The last name that is explained by The Deerslayer is "The Deerslayer." $\mathrm{He}$ gets the name after I [The Deerslayer] was rich enough to buy a rifle ...; "then ... I [The Deerslayer] could keep a wigwam in ven'son; and in time I [The Deerslayer] got the name of 'Deerslayer,' which is that I now bear; homely as some will think it, who set more value on the scalp of a fellow-mortal than on the horns of a buck (page 56)." In the next few chapters, the reader also know that he calls himself as "Eyehawk." This name is given to him as he kills an Indian in a very fair battle. Moreover it is the Indian, the one who is killed by him who gives him a warrior name. It is certain that relates to the name The Deerslayer tends to put himself as the red rather than the white. Native Americans regard their names not as mere labels, but as essential parts of their personalities. A native person's name is a vital to his or her identity.

\section{CONCLUSION}

Those three things; Indians, the setting, and the identity pursued by the main character; prove how Copper wants to shows the characteristics of American people. Through Indians, the readers know well that it is American's novel as Indians are the distinctive character of America as Indians can be only found in America. Next, the setting especially talking about the wilderness is also one of 
Cooper's ways to expose American features. That is why this wilderness which represents the artificiality of civilization, unspoiled nature, and path to spiritual and moral development becomes the distinct characteristic of America. Finally, the attempt of the main character to find his identity is the last Cooper's way to show American feature. The way Cooper compares the main character, The Deerslayer, and Hurry Skurry, another character of the novel, lets the readers to see and to find the answer what are American features. Besides, through names of the main character, the readers also can see that this is the way to describe the features of American characters. That is why, although in this novel as the main character is still young and Natty Bumppo or The Deerslayer is in the stage in finding the identity, this already helps the readers to know about American characteristics. Moreover, even though The Deerslayer still tries to figure out which is the best identity, in this journey to find his identity, the readers has found that the identity pursued by The Deerslayer describes America well. Finally, The Deerslayer can be said that it is an attempt to expose American Literature as some of American's features exposed in the story.

\section{REFERENCES}

American Romanticism. Retrieved data 13 October 2010. http://www.engdav.net/Notesfolder/11TH_GRADE_NOTES/american romanticism.htm

Easton, Stewart C. (1966). The Western Heritage. United Sates of America: Holt, Rineheart and Winston, Inc.

James Fennimore Cooper 1789-1851. Edited Appleton's Cyclopedia American Biography Copyright $\left(2001\right.$ by StanKlos.com ${ }^{T M}$. Retrieved data 13 October 2010. http:/www.jamesfenimorecooper.com/

James Fennimore Cooper. The Deerslayer. United States of America. Dood, Mead \& Company.

Johns, Joshua. Nature and the American Identity. Retrieved data 29 November 2010.

Leary, M. R., and Tangney, J. P. (2003). Handbook of Self and Identity. New York: Guilford Press.

Nash, Roderick. (1982). Wilderness and the American Mind. $3^{\text {rd }}$ Edition. New York: Vail-Ballou Press. 